\title{
AUTENTYZM VERSUS UDOSTĘPNIENIE. GRANICE KOMPROMISÓW W KONSERWACJI BYŁEGO OBOZU AUSCHWITZ-BIRKENAU ${ }^{1}$

\author{
Authenticity versus sharing. Boundaries of compromises in the \\ preservation of the former Auschwitz-Birkenau camp
}

Anna Łopuska*

\begin{abstract}
Preserving the Auschwitz-Birkenau site enables us to protect the memory that is retained in the historical objects. The meaning of the remnants of Auschwitz lies in their authenticity, which embodies, most of all, documentary and emotional values. These values, combined with the authentic character of the form, space and substance of the relics, evokes the need of special protection. Therefore, preservation of this unique site requires specific principles, suitable methodology, sensitivity, and primarily - the highest standards of ethics.

Since Auschwitz-Birkenau is not only a document of history, but also a museum, a memorial and, above all, a cemetery, it induces immense need for accessibility. Visitors coming from all over the world for family, historical and educational purposes search for the truth represented by
\end{abstract}

the original objects and wish to witness the authenticity in order to understand the unimaginable events.

How do we compromise between the authenticity and accessibility of the site? The preservation team at AuschwitzBirkenau Memorial deals with this dilemma on a daily basis, balancing different arguments and making difficult decisions. The results of their efforts may be illustrated with case studies including the preservation of two blocks in former Auschwitz I; conservation works performed together with adaptation of block 27 for the purpose of the Shoah exhibition, and last but not least, unprecedented works on the brick barracks of former Auschwitz II-Birkenau.

KEY WORDS: preservation, values, authenticity, accessibility, compromise

\section{AUTENTYZM, KONSERWACJA, EDUKACJA ${ }^{1}$}

Konserwacja jest jednym z dwóch filarów podstawowej działalności Państwowego Muzeum Auschwitz-Birkenau w Oświęcimiu, z których drugim jest edukacja. Zachowanie historycznych obiektów w ich autentycznej postaci niesie ze sobą wiarygodny przekaz, który stanowi fundament dla wszelkiej działalności edukacyjnej związanej z Miejscem Pamięci. Zatem o ile autentyzm ma znaczenie pierwotne, tak edukacja ma znaczenie wtórne, rozumiane jednak jako celowe. Autentyzm służy niewątpliwie edukacji, nie jest to jednak jego jedyna funkcja. Wiarygodność obiektów wiąże się bowiem ściśle z ich znaczeniem historycznym, dokumentalnym i emocjonalnym. Autentyzm jest zatem wartością pierwotną, nienaruszalną i stałą, a jego zachowanie kwestią bezsporną i jako taki stanowi punkt odniesienia dla edukacji, która przybierać może różne formy i wykorzystywać różnorakie możliwości, w zależności od aktualnych, zmieniających się potrzeb. Autentyzm jest również przedmiotem najwyższej ochrony i wyzwaniem dla konserwatorów, którzy adaptują wszelkie znane zasady, metody i środki,

\footnotetext{
Anna Łopuska, Auschwitz-Birkenau Memorial and Museum

1 Artykuł $\mathrm{w}$ języku angielskim o zbliżonej treści prezentowany będzie w materiałach konferencyjnych 2nd International Conference on Art \& Archaeology 2016, Art and Archaeology Strengthened by Measurement Techniques, December 11-14, 2016, Jerusalem, Israel.
} 
podporządkowując je prymatowi tej nadrzędnej wartości.

\section{ZASADY KONSERWATORSKIE}

Europejska teoria konserwacji, wykształcona na zrębach myśli Johna Ruskina, Aloisa Riegla, Maxa Dvorzaka, sprowadza się do zasadniczej idei poszanowania zabytkowej formy i substancji ${ }^{2}$. Zasady $\mathrm{z}$ tej podstawowej idei wynikające kształtowały się w drodze akademickiego rozwoju dziedziny konserwacji zabytków oraz międzynarodowych uzgodnień odzwierciedlonych w takich dokumentach jak Karta Ateńska (1931 r.), Karta Wenecka (1964 r.), Deklaracja Amsterdamska (1975 r.), Dokument z Granady (1985 r.), Deklaracja z Nara (1994 r.), Dokument z Pawii (1997 r.), Karta Krakowska (2000 r.), czy Memorandum Wiedeńskie (2005 r.).

W praktyce konserwatorskiej można mówić o siedmiu podstawowych zasadach konserwatorskich wynikających z obowiązujących kodeksów etyki zawodowej. Są to:

1) zasada primum non nocere (przede wszystkim nie szkodzić),

2) zasada maksymalnego poszanowania oryginalnej substancji zabytku i wszystkich jego wartości (materialnych i niematerialnych),

3) zasada minimalnej niezbędnej ingerencji (powstrzymywania się od działań niekoniecznych),

4) zasada, zgodnie z którą usuwać należy to (i tylko to), co na oryginał działa niszcząco,

5) zasada czytelności i odróżnialności ingerencji,

6) zasada odwracalności metod i materiałów,

7) zasada wykonywania wszelkich prac zgodnie z najlepszą wiedzą i na najwyższym poziomie. ${ }^{3}$

Zasady te pozostają w ścisłym związku z wartościami charakteryzującymi zabytek ${ }^{4}$, takimi jak: wartość historyczna, wartość dokumentalna, wartość komemoratywna, wartość estetyczna, wartość ekonomiczna, wartość użytkowa, wartość emocjonalna, wartość społeczna, wartość edukacyjna. Określenie wartości zabytku determinuje hierarchię ważności wspomnianych siedmiu zasad, a także pomaga w ich interpretacji i praktycznym zastosowaniu. Takie rozeznanie jest zaś kluczowe w podejmowaniu decyzji o tym co konserwować i jak konserwować ${ }^{5}$.

Pośród wyżej wymienionych wartości, wyróżnione zostały te, które mają szczególne znaczenie w przypadku obiektów Muzeum Auschwitz-Birkenau. Pozostałości po Auschwitz, w pierwszej kolejności stanowią zespół zabytków historycznych o znaczeniu dokumentu. Są nie tylko przestrogą dla przyszłych pokoleń, ale i dowodem historycznym przeciw każdemu, kto próbowałby podważyć zjawisko bądź skalę zbrodni popełnionych w Auschwitz. W czasach, gdy umierają ostatnie ofiary

2 Arszyński Marian, Idea - Pamięć - Troska. Rola zabytków w przestrzeni społecznej i formy działań na rzec ich zachowania od starożytności do połowy XX wieku, Malbork 2007, ss. 87-230; Szmygin Bogusław, Teoria zabytku Aloisa Riegla, [w:] Ochrona Zabytków Nr 3-4, 2003, ss.148-153.

3 Tezy do Krajowego programu ochrony zabytków i opieki nad zabytkami, [dokument elektroniczny: http://www.kobidz.home.pl/pliki/tezy.pdf ], s. 3 .

4 Frodl Walter, Pojęcia i kryteria wartościowania zabytków i ich oddziaływanie na praktykę konserwatorską, [w:] Biblioteka Muzealnictwa i Ochrony Zabytków, Seria B, t. XIII, Warszawa 1966.

5 Rouba Bogumiła, Wartościowanie w praktyce konserwatorskiej, [w:] Szmygin Bogusław (red.) Wartościowanie w ochronie i konserwacji zabytków. Warszawa-Lublin 2012, ss. 201-208. 


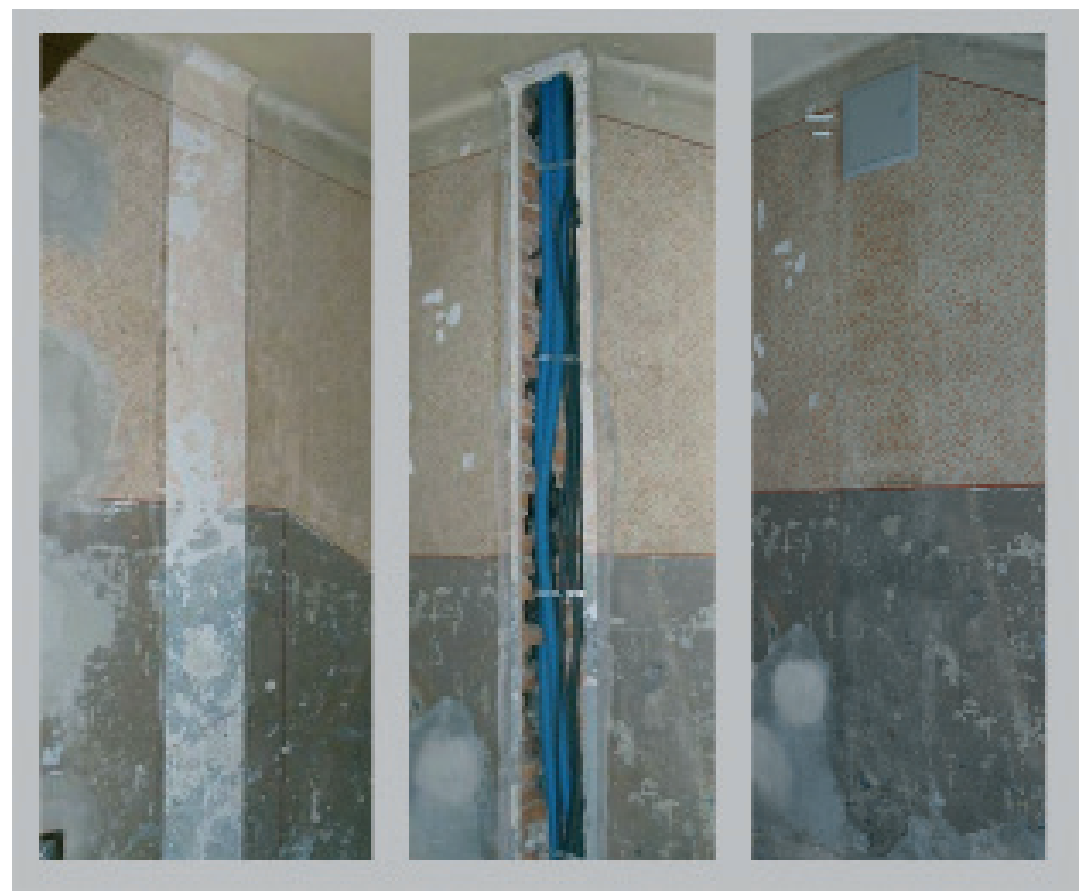

Il.01. Prace konserwatorskie w bloku 3. na terenie byłego KL Auschwitz I. Transfery warstw malarskich wykonane na potrzeby ukrycia niezbędnych instalacji elektrycznych.

Fot. Zbiory Państwowego Muzeum Auschwitz-Birkenau w Oświęcimiu, 2010-2013

i świadkowie Holokaustu, pozostałości po obozie pozostają jedynym materialnym świadectwem dramatycznych wydarzeń, które miały miejsce w Auschwitz. Właśnie jako dokumenty historii, zabytki te niosą wartości społeczne i edukacyjne, podczas gdy cmentarny charakter Auschwitz-Birkenau wiąże się z funkcją pielgrzymkową i upamiętniającą (komemoratywną).

U źródeł wszystkich wymienionych wyżej wartości leży powiązanie znaczenia wydarzeń historycznych z miejscem, w którym zaszły i z jego materią oraz formą i przestrzenią. Indywidualne obiekty w swojej liczbie stanowią zespół historyczny, który jako integralna całość także reprezentuje wartość autentyzmu. Forma, przestrzeń i kontekst są w tym wypadku nie mniej ważne niż materia. Układ baraków, rozwiązania przestrzenne, infrastruktura, zieleń - komponują widoki obozu, których autentyczny charakter można oceniać w zestawieniu z historycznymi zdjęciami, planami, czy treścią relacji byłych więźniów.

Autentyzm i wiarygodność to najważniejsze atrybuty pozostałości po Auschwitz, dlatego ochrona i zachowanie tych właśnie wartości jest pierwszorzędnym celem konserwacji. Dzieje się to poprzez priorytetyzację i adaptację zasad konserwatorskich w następujący sposób:

1. stosowanie zasady maksymalnego poszanowania oryginalnej substancji zabytku i wszystkich jego wartości

2. konserwację profilaktyczną, 
3. konserwację zachowawczą/techniczną,

4. stosowanie zasady minimalnej niezbędnej ingerencji,

5. utrwalenie bądź uczytelnienie estetyki konserwowanych przedmiotów zgodnej z ich wyglądem z czasu funkcjonowania obozu, kluczowego dla ich historycznego znaczenia,

6. stosowanie zasady czytelności i odróżnialności ingerencji

$\mathrm{Z}$ zasad tych wywodzą się bardziej szczegółowe wytyczne, dotyczące konserwacji poszczególnych obiektów bądź grup obiektów (vide: Jolanta Banaś-Maciaszczyk, Rafał Pióro, Problematyka konserwatorska i założenia ochrony obiektów dawnego KL Auschwitz-Birkenau, artykuł publikowany w niniejszym czasopiśmie) $^{6}$.

Rozwój szczególnego kodeksu etyki w dziedzinie konserwacji zabytków martyrologicznych może być śledzony poprzez analizę działalności konserwatorskiej Muzeum Auschwitz-Birkenau na przestrzeni ostatnich 70-ciu lat. Refleksja związana $\mathrm{z}$ adaptacją i praktycznym stosowaniem zasad konserwatorskich towarzyszyła między innymi powstaniu pracowni konserwatorskich w Muzeum, a także wszystkim projektom konserwatorskim dotyczącym zarówno zabytków ruchomych, jak i budynków, ruin i terenu byłego obozu.

\section{UDOSTĘPNIENIE}

Auschwitz-Birkenau to dokument historii, ale także muzeum, miejsce pamięci i cmentarz, dlatego wymaga możliwie jak największego udostępnienia zwiedzającym. Liczba zwiedzających nieustająco wrasta, sięgając rekordowego poziomu, ponad 2 milionów w 2016 roku. Ludzie z całego świata przyjeżdżają aby doświadczyć tego miejsca osobiście i potrzebują możliwie szerokiego dostępu.

Udostępnienie obiektów historycznych wiąże się z dwoma zasadniczymi problemami. Po pierwsze, ruch turystyczny może być jednym z czynników niszczących (wraz z czynnikami atmosferycznymi, starzeniem się materiałów itp.). Po drugie, udostępnienie obiektów wymaga stosowania środków bezpieczeństwa, które często wiążą się z koniecznością ingerencji, zwłaszcza w budynkach. W ten oto sposób ochrona autentyzmu i zapewnienie dostępu zwiedzającym jawią się jako konflikt interesów. Pogodzenie ochrony wartości dokumentalnych z udostępnieniem wymaga podejmowania trudnych decyzji, których rezultatem jest zawsze jakiś kompromis. W przypadku budynków historycznych, największym wyzwaniem jest równoległe osiągnięcie trzech celów:

zachowanie historycznej materii, formy i przestrzeni;

zapewnienie bezpiecznego dostępu do budynku (wymagające zwykle wzmocnienia konstrukcji budynku, zastosowanie norm pożarowych itp.);

osiągnięcie rezultatu estetycznego eksponującego walor autentyzmu i spełniającego oczekiwania zwiedzających.

Należy w tym miejscu zaznaczyć, iż oczekiwania zwiedzających mogą byś różne i mają drugorzędne znaczenie

6 Banaś Jolanta, Cyrulik Ewa, Papis Aleksandra, Pióro Rafał, Programy konserwatorskie dla bloków o nr inw. A-2 i A-3, Czesść pierwsza - Wprowadzenie, Dział Konserwacji PMA-B w Oświęcimiu, 2007, (praca niepublikowana); Łopuska Anna, Założenia konserwatorskie dla baraków murowanych na odcinku BI dawnego KL Auschwitz II-Birkenau, Oświęcim 2014, (praca niepublikowana). 
wobec priorytetu, jakim jest zachowanie autentyzmu? ${ }^{7}$ Ostatecznie, to właśnie autentyczny charakter miejsca sprawia, że zwiedzający są zainteresowani odwiedzeniem go.

\section{KOMPROMIS - PRZYKŁADY}

Zasady konserwatorskie stanowią ramy możliwych wyborów, jednak poszczególne rozwiązania wypracowywane są indywidualnie dla każdego obiektu. Charakter obiektu, jego historia, stan zachowania są punktem wyjścia do opracowania najlepszych metod konserwacji. Rozwiązania planowane są na etapie projektów i programów prac konserwatorskich, a niekiedy dostosowywane w trakcie prac, w odniesieniu do aktualnego stanu wiedzy oraz rozpoznania możliwości i ograniczeń, jakie stwarza obiekt. Zatem zasady konserwatorskie stosowane są w odniesieniu do charakterystyki obiektu, któremu służą, nigdy na odwrót. Poniżej prezentowane są trzy różne przykłady realizacji konserwatorskich będące obrazem różnych podejść i rozwiązań.

\subsection{Konserwacja dwóch bloków rezerwatowych w byłym KL Auschwitz I (2010-2013)}

Konserwacja bloków 2. i 3. trwała ponad trzy lata i była jednym z największych i najważniejszych projektów konserwatorskich zrealizowanych w Muzeum Auschwitz-Birkenau w ostatnich latach. Głównym celem projektu było zachowanie autentycznego charakteru rezerwatowych budynków i jednoczesne poprawienie ich stanu technicznego oraz eliminacja przyczyn postępujących zniszczeń. Rezultatem prac miało być również udostępnienie zwiedzającym wnętrz budynków, które ze względu na stan techniczny pozostawały niedostępne.

\begin{tabular}{|c|c|c|c|}
\hline Złożon: & problematyka & konserwatorska & interdyscypli- \\
\hline & specjalistów & reprezentujacych & dziedziny, \\
\hline
\end{tabular}
i ceramiki, konserwacja drewna, archeologia, budownictwo w branżach konstrukcyjno-budowlanej, sanitarnej i elektrycznej'. Szczególnie trudnym zadaniem było ograniczenie do minimalnej interwencji przy konieczności zabudowania nowych instalacji niezbędnych do zapewnienia budynkom odpowiednich warunków temperaturowo-wilgotnościowych. Zachowanie autentycznego charakteru budynku i jego wnętrz było celem nadrzędnym, dlatego oryginalne elementy wyposażenia zostały maksymalnie wykorzystanie do ukrycia instalacji ${ }^{10} \mathrm{i}$ zastosowane zostały zupełnie nietypowe rozwiązania, "szyte na miarę".

W bloku 2., na potrzeby ukrycia instalacji grzewczych, pod budynkiem wykopana i przystosowana została nowa piwnica, a rozprowadzenie urządzeń grzewczych do niektórych pomieszczeń parteru ukryto w rurach nieczynnej kanalizacji. W bloku 3. z kolei, wykonano transfery dekoracji ściennych w celu ukrycia w ścianie instalacji elektrycznej oraz zastosowania wzmocnień konstrukcyjnych. Transferowane nawarstwienia wrócily na swoje miejsce w nienaruszonym stanie. W rezultacie

\footnotetext{
Kobyliński Zbigniew, Paczuska Agnieszka, Poglady młodzieży liceów warszawskich na temat zabytków: czy teorie konserwatorskie są zgodne z oczekiwaniami społecznymi?, [w:] Ochrona Zabytków Nr 2, Warszawa 2007, ss. $81-92$

8 Juras Oliwia, Setkiewicz Piotr, Łopuska Anna, Zachować autentyzm. Konserwacja dwóch bloków dawnego KL Auschwitz I, Oświęcim 2013, s. 6.

9 Ibidem, s. 56.

10 Ibidem, s. 6.
} 
wszelkie elementy techniczne ukryte zostały w sposób minimalizujący ich widoczną obecność w historycznej przestrzeni, a zwiedzającym udostępniono dwie kondygnacje budynków wraz ze wszystkimi historycznymi pomieszczeniami, w stanie maksymalnie zbliżonym do tego, w którym znajdowały się, gdy ostatni więźniowie opuszczali bloki.

4.2. Prace konserwatorskie związane $\mathrm{z}$ adaptacją bloku 27. na potrzeby wystawy „Shoah” (2011-2013)

Prace konserwatorskie w bloku 27. na terenie byłego KL Auschwitz I towarzyszyły adaptacji budynku na potrzeby nowej wystawy, która zastąpiła poprzednią ekspozycję opisującą losy żydowskie w obozie zagłady. Projekt wystawy zawierał liczne współczesne rozwiązana ekspozycyjne i instalacje, takie jak choćby klimatyzacja, czy instalacje zasilające urządzenia audiowizualne, a także uwzględniał dostosowanie pomieszczeń bloku do scenariusza oprowadzania. Szczególnym wyzwaniem było pogodzenie racji konserwatorskich i potrzeb funkcjonalnych w obiekcie. Dodatkową trudność stanowił międzynarodowy charakter projektu. Organizatorem wystawy była izraelska instytucja Yad Vashem, w związku z czym znaczna część projektów i dokumentacji technicznej powstawała w Izraelu, po czym implementowana była w Polsce, z uwzględnieniem lokalnych uwarunkowań formalnych i technicznych. Kluczowe decyzje podejmowane były $\mathrm{w}$ międzynarodowym i interdyscyplinarnym gronie polskich i izraelskich specjalistów.

Wnętrze budynku zostało w znaczący sposób przekształcone po wojnie, w związku z wprowadzeniem poprzedniej wystawy, dlatego zachowało się w nim mniej autentycznych pozostałości, niż w blokach tzw. rezerwatowych, takich jak opisywane wyżej blok 2. i 3. Taki stan zachowania budynku kwalifikował go zatem do przystosowania na cele nowej wystawy. Prace konserwatorskie nie stanowiły w tym wypadku głównego celu projektu, jakkolwiek towarzyszyły wszystkim działaniom, na każdym ich etapie. W tym przypadku ekspozycja oryginalnych elementów została ograniczona, gdyż nie grają one pierwszorzędnej roli w narracji scenariusza wystawy i w jej przekazie. Nie mniej jednak, wszystkie historyczne pozostałości zostały zabezpieczone i pomimo, że nie są dziś widoczne (nawarstwienia ścienne przysłonięte są ściankami kartonowo-gipsowymi, a pozostałości oryginalnej posadzki schowane pod posadzką przystosowaną do eksploatacji przez ogromne liczby odwiedzających), pozostają bezpieczne i mogą zostać wyeksponowane w dowolnym czasie w przyszłości. Wystawa zainstalowana została w zgodzie z zasadą odwracalności zastosowanych środków. W trakcie prac odkryte zostały malowidła ścienne wykonane przez więźniów, w związku z czym wyeksponowano je w przestrzeni klatki schodowej i włączono do wystawy. 


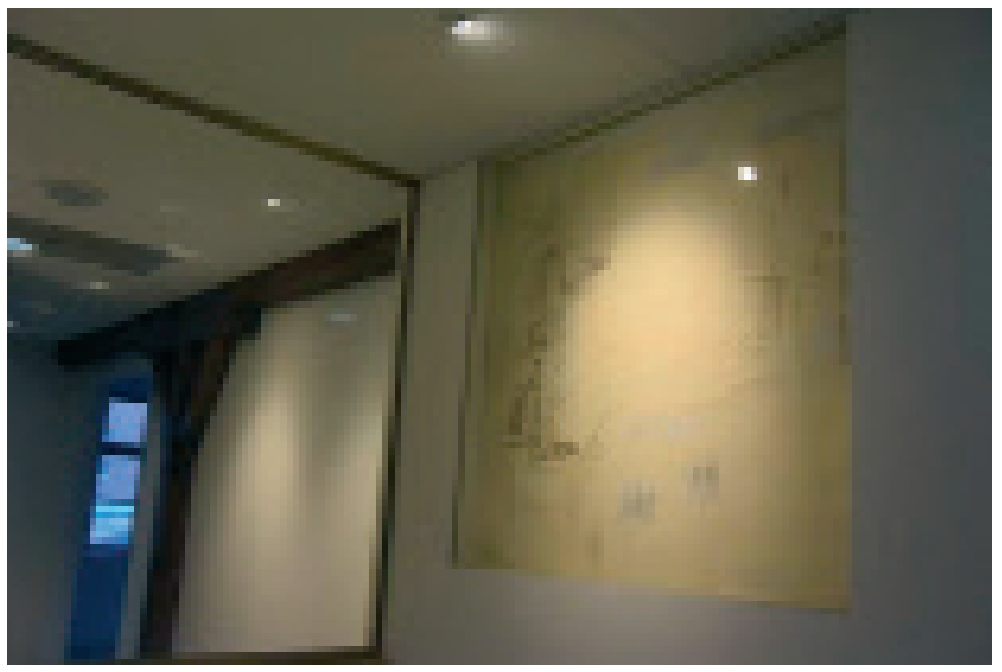

Il.02. Ekspozycja Shoah w bloku 27. na terenie byłego KL Auschwitz I. Odkryte w trakcie prac konserwatorskich malowidło zostało wyeksponowane i włączone do wystawy. Fot. Anna Łopuska, 2016

4.3. Konserwacja baraków murowanych na terenie byłego KL Auschwitz II-Birkenau (2015 ）

Konserwacja zespołu 45 baraków murowanych w obszarze odcinka BI byłego KL Auschwitz II-Birkenau to jedno z największych wyzwań Globalnego Planu Konserwacji, wieloletniego projektu konserwatorskiego mającego na celu zachowanie wszystkich pozostałości po Auschwitz i finansowanego ze środków Fundacji Auschwitz-Birkenau. W ostatnich latach większość tych budynków została zamknięta dla zwiedzających ze względu na ich zły stan zachowania. Baraki, które przetrwały do dnia dzisiejszego w charakterze rezerwatu cechuje mnóstwo problemów związanych z wyjątkowo lichą, niezgodną z normami budowlanymi, techniką budowy, czynnikami atmosferycznymi i brakiem systematycznych i holistycznych działań zabezpieczających w przeszłości, spowodowanych niedostatecznym poziomem funduszy. 


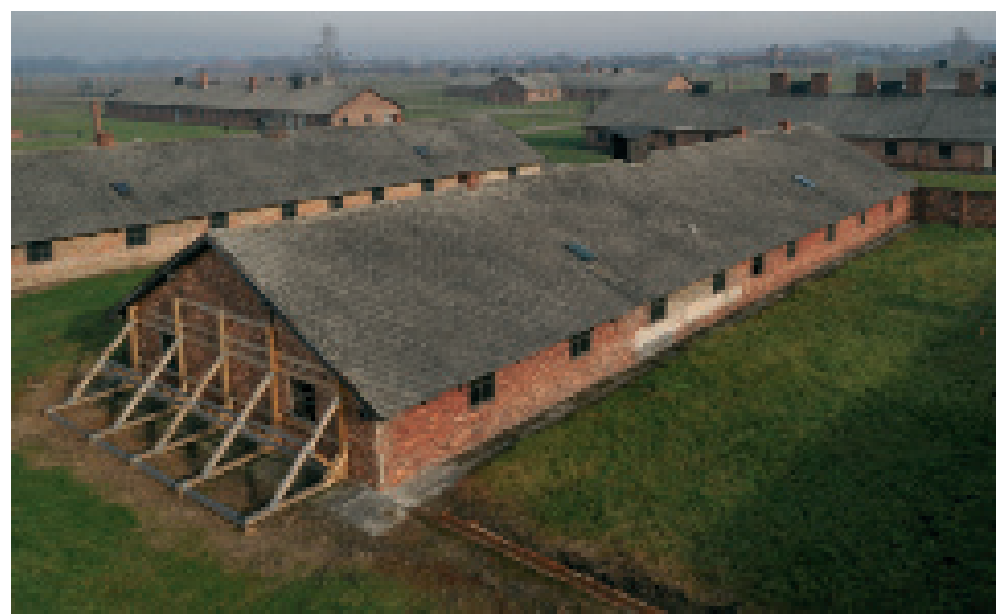

Il.03. Barak murowany na terenie byłego KL Auschwitz I. Tymczasowe podpory zabezpieczają ścianę baraku. Fot. Łukasz Szoblik, 2013

Baraki wzniesione zostały w latach 1941/1942, przy czym znaczna część procesu budowlanego miała miejsce w okresie jesiennym i zimowym. Do budowy kompleksu wykorzystano przymusową siłę roboczą składającą się z wyczerpanych sowieckich jeńców wojennych, którzy masowo umierali przy pracy ${ }^{11}$. Materiał budowlany w postaci cegieł i drewnianych elementów konstrukcyjnych pozyskany został z rozbiórki domostw należących do wcześniej wysiedlonych mieszkańców wsi Brzezinka, a konstrukcja baraków daleka była od jakichkolwiek standardów. Pośród najbardziej niebezpiecznych wad elementów konstrukcyjnych wymienić należy zbyt płytkie fundamenty lub ich całkowity brak, brak odpowiedniej izolacji, smukłość i niewielką szerokość ścian (w większości wypadków $12 \mathrm{~cm}$ ) oraz niedostateczne przekroje elementów drewnianych. Eksploatacja tych budynków zaplanowana była jedynie na kilka lat funkcjonowania fabryki śmierci i nikt w tamtym czasie nie zamierzał utrzymywaćich przezkolejnych ponad 70 lat, które upłynęłyod czasu budowy. W tym czasie obiekty te nieustannie eksponowanebyłyna działanieczynnikówniszczących, takichjaksilnewiatry, woda, mróz,korozjabiologiczna $\mathrm{i}$ intensywny ruch odwiedzających.

Zagadnienia konserwatorskie związane z barakami więźniarskim są nietypowe pod wieloma względami. Nie istnieją podobne obiekty w zbliżonym stanie zachowania, objęte ścisłą ochroną konserwatorską. Nawet jeśli gdzieś ma świecie powstały budynki o podobnej konstrukcji, z pewnością nie są one przedmiotem zabiegów konserwatorskich mających na celu zachowanie ich autentycznej formy. Unikalny charakter tych obiektów sprawia, że trudno się odnieść do doświadczeń konserwatorskich, które stanowiłyby wymierny punkt odniesienia lub przykład do naśladowania.

11 Czech Danuta, Konzentrationslager Auschwitz - zarys historyczny, [w:] Oświęcim hitlerowski obóz zagłady, Wydawnictwo Interpress, Warszawa 1987, s. 24; Czech Danuta Geneza obozu, jego budowa i rozbudowa, [w:] Piper Franciszek, Świebocka Teresa (red.), Auschwitz nazistowski obóz śmierci, Wydawnictwo Państwowego Muzeum Oświęcim-Brzezinka 2006, ss. 30-31; Strzelecka Irena, Budowa, rozbudowa oraz rozwój obozu ijego filii, [w:] Auschwitz 1949-1945. Węzłowe zagadnienia z dziejów obozu, T. IZałożenie i organizacja obozu, Oświęcim 1995, s.56. 
Autentyzm versus udostępnienie. Granice kompromisów w konserwacji byłego [...]

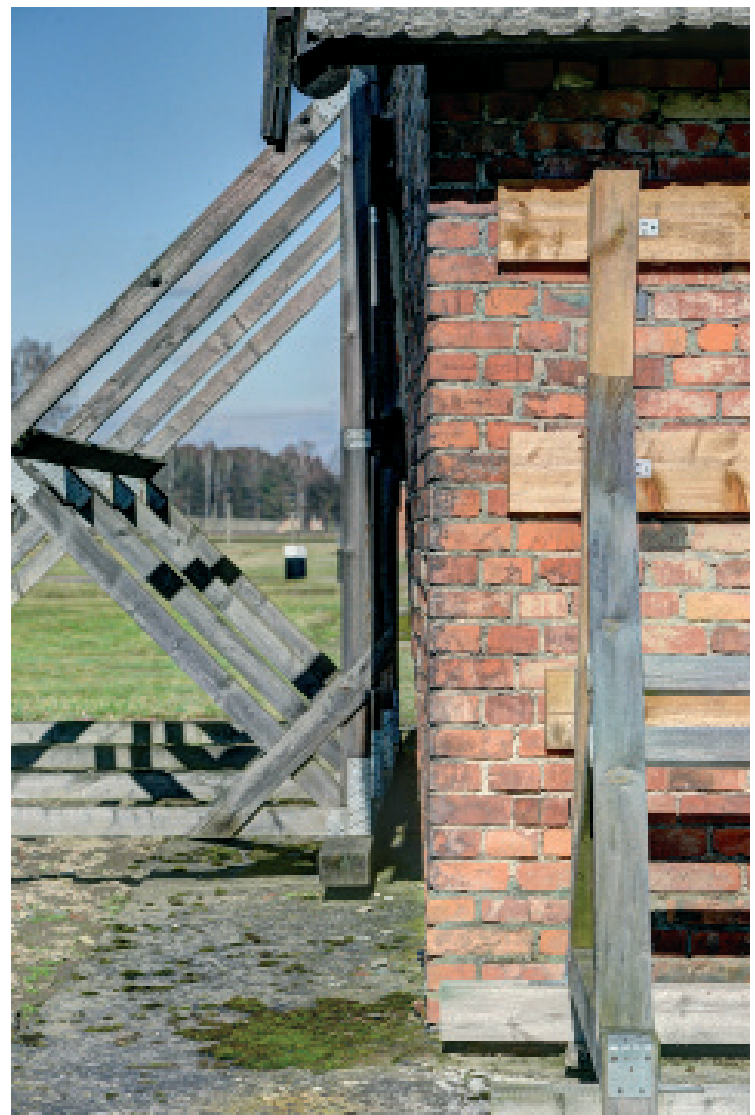

Il.04. Barak murowany na terenie byłego KL Auschwitz I. Widoczna silna deformacja ściany szczytowej. Fot. Kamil Będkowski, 2016 
Przygotowanie programów prac konserwatorskich i projektów budowlanych dla murowanych baraków wymagało całościowej oceny ich stanu zachowania, analizy mechanizmów i przyczyn zniszczeń oraz opracowania kompleksowych metod konserwatorskich. W tym celu uruchomiony został szeroko zakrojony program badawczy angażujący osiem ośrodków naukowych realizujących badania w poszczególnych dziedzinach. Projekt zrealizowany został w latach 2013-2016 i objął następujące zagadnienia:

- Badania nad korozją biologiczną obiektów na terenie Państwowego Muzeum AuschwitzBirkenau w zakresie rozpoznania i zwalczania czynników biologicznych ${ }^{12}$;

- Badania nad opracowaniem metod konserwacji, zabezpieczenia i wzmocnienia konstrukcji obiektów, elementów ich wykończenia oraz ich podłoża gruntowego z uwzględnieniem statyki i fizyki budowli, obiektów występujących na terenie Państwowego Muzeum Auschwitz-Birkenau ${ }^{13}$;

- Badania techniki, technologii i stanu zachowania nawarstwień malarskich występujących w obiektach na terenie Państwowego Muzeum Auschwitz-Birkenau oraz badania nad opracowaniem metod ich konserwacji i zabezpieczenia;

- Badania nad sposobem konserwacji, zabezpieczania i wzmocnienia historycznych elementów drewnianych występujących w obiektach na terenie Państwowego Muzeum Auschwitz-Birkenau;

12 Koziróg Anna, Otlewska Anna, Piotrowska Małgorzata, Rajkowska Katarzyna, Nowicka-Krawczyk Paulina, Hachulka Mariusz, Wolski Grzegorz J., Gutarowska Beata, Kunicka-Styczyńska Alina, Żydzik-Białek Agnieszka, Colonising organisms as a biodegradation factor affecting historical wood materials at the former concentration camp of Auschwitz II - Birkenau, [w:] International Biodeterioration \& Biodegradation, Vol. 86 Part B. 2014;

Nowicka-Krawczyk Paulina, Żelazna-Wieczorek Joanna, Otlewska Anna, Koziróg Anna, Rajkowska Katarzyna, Piotrowska Małgorzata, Gutarowska Beata, Żydzik-Białek Agnieszka, Diversity of an aerial phototrophic coating of historic buildings in the former Auschwitz II-Birkenau concentration camp, [w:] Science Of The Total Environment, Vol. 493, 2014; Otlewska Anna, Adamiak Justyna, Gutarowska Beata, Clone-based comparative sequence analysis of $16 S$ rRNA genes retrieved from biodeteriorating brick buildings of the former Auschwitz II-Birkenau concentration and extermination camp, [w:] Systematic And Applied Microbiology, Vol. 38. 2015; Piotrowska Małgorzata, Otlewska Anna, Rajkowska Katarzyna, Koziróg Anna, Gutarowska Beata, Żydzik-Białek Agnieszka, Zanieczyszczenie mikrobiologiczne wybranych obiektów na terenie Państwowego Muzeum Auschwitz-Birkenau w Oświęcimiu, [w:] Ochronaprzed Korozją, Vol.9s/A/2012; Rajkowska Katarzyna, Otlewska Anna, Koziróg Anna, Piotrowska Małgorzata/Nowicka-Krawczyk Paulina, Hachulka Mariusz, Wolski Grzegorz J., Kunicka-Styczyńska Alina, Gutarowska, Beata, Żydzik-Białek Agnieszka, Assessment of Biological Colonization of Historic Buildings in The Former Auschwitz II-Birkenau Concentration Camp, [w:] Annals of Microbiology, Vol. 64. 2014.

13 Matysek Piotr, Stryszewska Teresa, Kańka Stanisław, Experimental studies of brick masonry in the Auschwitz II - Birkenau former death camp buildings, [w:] Brick and Block Masonry: trends, innovations and challenges [proceedings of the 16th International Brick and Block Masonry Conference (IBMAC 2016), 26-30 June 2016, Padwa 2016; Matysek Piotr, Stryszewska Teresa, Kańka, Stanisław, Experimental research of masonry compressive strength in the Auschwitz II - Birkenau former death camp buildings, [w:] Engineering Failure Analysis, Vol. 68. 2016; Kańka Stanisław, Stryszewska Teresa, Tracz Tomasz, Karczmarczyk Stanisław, Paruch Roman, Methods of testing and assessing the technical condition of chosen building structures located in the area of the Auschwitz-Birkenau National Museum in Oświęcim, [w:] Civil and Environmental Engineering Reports, Vol. 19; 18. 2015; Stryszewska Teresa, Kańka Stanisław, Żydzik-Białek Agnieszka, Research methods adopted for evaluation of the condition of the building materials used in construction of the masonry structures on the site of the Auschwitz-Birkenau State Museum in Oświęcim, [w:] Procedia Engineering, Vol. 108. 2015. 
- Badania nad identyfikacją materiałów budowlanych, określające właściwości fizyko-chemiczne i wytrzymałościowe oraz badania nad sposobem konserwacji, zabezpieczenia i wzmocnienia elementów z materiałów mineralnych, występujących w obiektach na terenie Państwowego Muzeum Auschwitz-Birkenau;

- Badania nad konserwacją i zabezpieczeniem żelbetu występującego w obiektach na terenie Państwowego Muzeum Auschwitz-Birkenau;

- Badania skuteczności materiałów i metod w zabezpieczaniu antykorozyjnym oraz oczyszczaniu elementów metalowych występujących w obiektach na terenie Państwowego Muzeum Auschwitz-Birkenau.

Jednym z najciekawszych problemów ilustrujących konflikt pomiędzy ratowaniem autentyzmu a potrzebą udostępnienia obiektów jest zagadnienie prostowania i stabilizacji ścian baraków, które wykazują liczne deformacje i odchylenia od pionu. W obecnej chwili znaczna część ścian zabezpieczona jest przed zawaleniem przy pomocy tymczasowych drewnianych podpór i gorsetów, które zaburzają wygląd budynków i autentycznej przestrzeni. W celu ustabilizowania całej konstrukcji budynku, ściany należy przywrócić do pionu, skorygować niektóre deformacje, powstałe w wyniku pracy gruntu, oraz całość wzmocnić w sposób skuteczny i niewidoczny oraz pozwalający na demontaż doraźnych zabezpieczeń.

Celem jednego z projektów badawczych było opracowanie metod prostowania i wzmacniania ścian bez konieczności ich przemurowywania. Zaprojektowane metody zostały sprawdzone na specjalnie przygotowanych replikach ściany, najpierw w warunkach laboratoryjnych na Politechnice Krakowskiej, a następnie w warunkach polowych ${ }^{14}$. Po serii przeprowadzonych testów weryfikujących skuteczność metod i ich bezpieczeństwo, wkrótce nastąpi próba ich zastosowania w barakach. Choć zabieg prostowania wywołał pęknięcia ścian wymagające naprawy, jest on alternatywą dla przemurowania ściany, które niewątpliwie obniżyłoby poziom jej autentyzmu.

14 Matysek Piotr, Stryszewska Teresa, Kańka Stanisław, Experimental studies of brick masonry in the Auschwitz II - Birkenau former death camp buildings, [w:] Brick and Block Masonry: trends, innovations and challenges [proceedings of the 16th International Brick and Block Masonry Conference (IBMAC 2016), 26-30 June 2016, Padwa 2016; Matysek Piotr, Stryszewska Teresa, Kańka, Stanisław, Experimental research of masonry compressive strength in the Auschwitz II - Birkenau former death camp buildings, [w:] Engineering Failure Analysis, Vol. 68. 2016. 


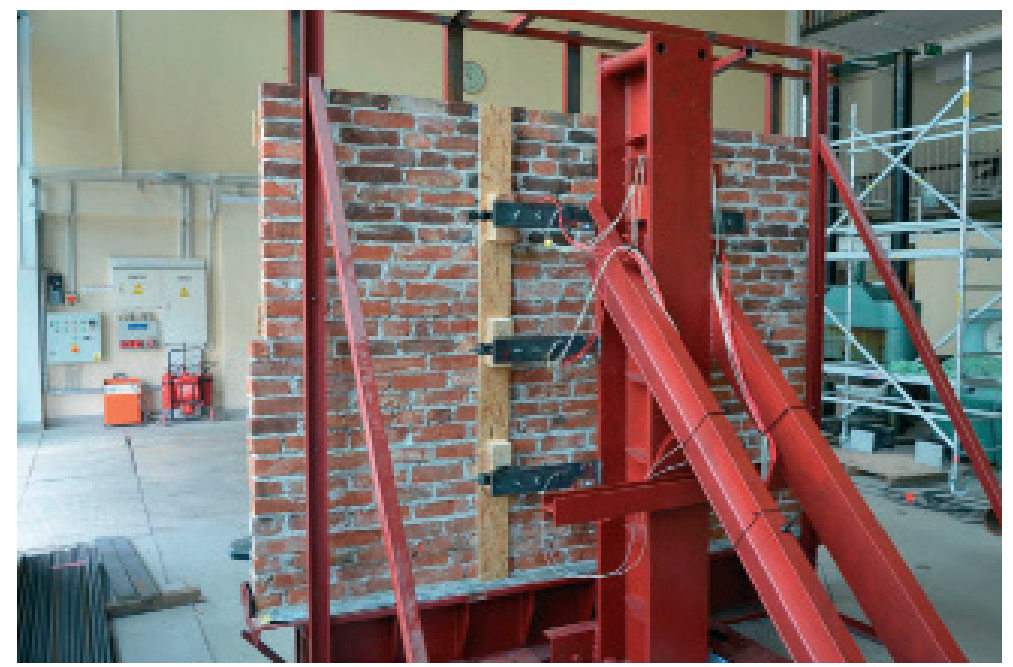

Il.05. Opracowanie metody prostowania ściany I likwidacji deformacji na specjalnie przygotowanej replice ściany. Fot. Politechnika Krakowska, 2016

\section{PODSUMOWANIE}

Opisane powyżej trzy przykłady realizacji konserwatorskich przedstawiają trzy sytuacje, w których, bazując na tych samych zasadach i założeniach, zastosowano zupełnie różne rozwiązania godzące potrzebę zachowania autentyzmu i udostępnienia obiektów. Każda ingerencja w obiekt zabytkowy, każda próba dostosowania go do aktualnych potrzeb musi być rozważana w zestawieniu z zagrożeniem pomniejszenia jego autentycznej wartości. Dlatego w Miejscu Pamięci, zasada minimalnej ingerencji jawi się jako pierwsza i najważniejsza ze wszystkich zasad konserwatorskich, a indywidualne rozwiązania i kompromisy wypracowywane są z uwzględnieniem prymatu ochrony autentyzmu. 